\title{
PELATIHAN METODE SAJARAH AL-MÎRÂTS DALAM MEMAHAMI HUKUM WARIS PADA KIYAI PESANTREN DARUSSALAM PARMERAAN PADANG LAWAS UTARA
}

\author{
Suryadi Nasution 1), Raja Ritonga2), Muhammad Ikbal'), Parulian Siregar ${ }^{3)}$, Akhyar $^{4)}$ \\ 1)Prodi Pendidikan Agama Islam Sekolah Tinggi Agama Islam Negeri Mandailing Natal \\ 2)Prodi Hukum Islam Sekolah Tinggi Agama Islam Negeri Mandailing Natal \\ 1)Prodi Pendidikan Agama Islam Sekolah Tinggi Agama Islam Negeri Mandailing Natal \\ 3)Prodi PGMI Sekolah Tinggi Agama Islam Negeri Mandailing Natal \\ 4)Prodi Hukum Ekonomi Syariah Sekolah Tinggi Agama Islam Negeri Mandailing Natal \\ Corresponding author: Suryadi Nasution \\ Email: Suryadinst@stain-madina.ac.id
}

Diterima 08 April 2021, Direvisi 15 April 2021, Disetujui 15 April 2021

\begin{abstract}
ABSTRAK
Pengabdian ini bertujuan untuk memberikan pelatihan metode sajarah al-mirast kepada para guru Pondok Pesantren Darussalam Parmeraan Padang Lawas Utara untuk memudahkan dalam memahami hukum waris. Metode yang digunakan dalam pelatihan ialah participat opproach dimana semua guru terlibat aktif dalam kegiatan pelatihan selama dua hari. Dari pelatihan yang dilakukan, semua guru pesantren, baik yang berlatar belakang Pendidikan agama maupun umum, mengerti dan mampu menerapkan hukum waris secara baik. Pelatihan ini juga mendapatkan respon yang cukup antusias karena disambut dengan sebuah rekomendasi untuk melanjutkan program pada pesantren atau Lembaga Pendidikan Islam lainnya.
\end{abstract}

Kata kunci: sajarah al-mirast; mawaris; guru pesantren

\begin{abstract}
This service aims to provide training in the sajarah al-mirast method to teachers of the Darussalam Parmeraan Islamic Boarding School in Padang Lawas Utara to make it easier to understand the law of warist. The method used in the training is participatory opproach where all the teachers are actively involved in training activities for two days. From the training that was carried out, all of the teachers of the rapid trends, both those with religious and general education backgrounds, understood and were able to properly apply the law of inheritance. This training also received an enthusiastic response because it was greeted with a recommendation to continue the program at pesantren or other Islamic education institutions.
\end{abstract}

Keywords: sajarah al-mirast; mawaris; pesantren teachers

\section{PENDAHULUAN}

Figh mawaris merupakan aturan hukum dalam agama Islam, berfungsi untuk mengatur dan menjelaskan tentang peralihan kepemilikan harta dari seseorang kepada orang lain (Suryati, 2017:2). Pengamalan ilmu mawaris sangat erat kaitannya dengan pengetahuan tentang mawaris itu sendiri. Rasullullah Saw menggambarkan bahwa keberadaan ilmu mawaris termasuk ilmu yang pertama kali diangkat oleh Allah Swt dari umat ini (Kurnia, 2020: 22). 'Ramalan' Rasulullah saw., tersebut pada gilirannya menjadi misteri yang nyata, dalam banyak studi yang dilakukan diberbagai Lembaga Pendidikan Islam, mulai dari madrsah hingga pesantren, statement sulitnya memahami hukum waris selalu terdengar, tidak hanya bagi kalangan pelajar, namun juga para guru (Hasanuddin, 2020,V).

\begin{abstract}
Minimnya pemahaman terhadap konsep mawaris secara tuntas membuat pengamalan ilmu ini tidak terlalu massif terlebih dalam hal praktis. Alquran menjelaskan bahwa aturan tentang mawaris merupakan undangundang Allah Swt dan harus diamalkan sesuai dengan tuntunan yang ada. Allah Swt memberikan sanjungan dengan kemenangan yang sangat agung karena mengamalkan mawaris. Sedangkan orang yang tidak mengamalkan mawaris secara benar, mereka digolongkan kelompok yang durhaka terhadap perintah Allah Swt dan mendapat siksa di akhirat. Pernyataan ini termaktub dalam firmanNya (Q.S.4:12-13).

Lembaga pendidikan di Indonesia, seperti dunia pesantren selalu berupaya untuk menghadirkan konsep dan metode yang terkini untuk menguraikan ilmu-ilmu praktik. Fiqh
\end{abstract}


Mawaris selalu menjadi momok yang menakutkan bagi para santri. Sehingga proses transfer pengetahuan terkait mawaris sering mandek dan tidak berkembang. Padahal teori mawaris merupakan ajaran yang sudah baku dalam ajaran Islam. Pada prinsipnya, sesuatu yang sudah baku akan lebih mudah untuk diuraikan dan dijelaskan.

Hukum mawaris adalah salah satu hukum eksak dalam Islam yang secara rill dan rinci dijelaskan dalam Alquran. Namun hal ini tidak berbanding lurus terhadap pengetahuan umat Islam pada umumnya. Kajian perbedaan hukum Islam sering dijumpai dalam berbagai literatur yang memuat khilafiah, dan eksistensi (Hanafiah, 2019, 68-86), namun sepertinya cukup jarang dikalangan umat Islam memahami hukum pasti ini (mawaris) sebagai salah satu ajaran pokok Islam. Tidak hanya dikalangan umum, Lembaga Pendidikan seperti Pesantren juga mempunyai potret yang sama, tidak hanya dikalangan santri, namun mayoritas tenaga pengajar di Pesantren juga merasakan demikian. Sehingga kitab-kitab dan buku panduan terkait mawaris kurang dikuasai secara maksimal oleh santri. Akibatnya pengetahuan para santri masih sangat minim dalam menguasai teori dan praktik ilmu mawaris.

Cukup banyak tawaran untuk menghilangkan stigma sulitnya pelajaran mawaris, salah satunya ialah dengan membangun konsep, pendekatan, atau metode baru untuk mempermudah memahami hukum waris. Terdapat kajian penelitian terapan maupun banyak metode yang ditawarkan untuk mempelajari mawaris, di antaranya menggunakan Aplikasi al-Faraidh (Sujud, 2017: 15-23), melalui Video Sparkol (Fahmi, 2017: 229-238), melalui Aplikasi At-Tashil (Nurdin, 2020, 402-427) dan berbagai macam pendekatan pembelajaran lainnya dalam upaya mempermudah memahami mawaris.

Konsep yang kemudian masyhur di timur tengah ialah metode sajarah al-mirast, yaitu metode pembelajaran mawaris dengan pendekatan menggambarkann semua ahli waris pada sebuah pohon. Metode ini merupakan pembelajaran mawaris dengan cara yang sangat simpel dan terstruktur. Dalam metode ini para ahli waris digambarkan pada pohon dengan garis klasifikasi yang jelas dan mudah untuk dibedakan. Identifikasi para ahli waris dengan sistem kekerabatan yang paling dekat kepada orang yang meninggal.
Selanjutnya penentuan bagian masing-masing ahli waris dengan mengkoneksikan terhadap keberadaan ahli waris yang lain.

Pondok Pesantren Darussalam Parmeraan, Kec. Dolok, Kab. Padang Lawas Utara adalah salah satu lokasi Pengabdian Dosen Sekolah Tinggi Agama Islam Negeri Mandailing Natal (STAIN Madina). Pesantren ini menarik menjadi subjek pengabdian karena beberapa hal, diantarnya karena pesantren Darussalam merupakan pondok pesantren tradisional terbesar di Padang lawas utara dengan jumlah santri lebih dari 1200 , pesantren ini mempunyai lokasi yang cukup terisolir sehingga cukup sepi dari isu modernisasi Pendidikan, pesantren ini juga mempunyai komitment dalam menjaga Identitas dalam kajian-kajian keislama melalui literatur kitabkitab turast.

Tujuan dari pengabdian ini ialah untuk memberikan pelatihan kepada para guru/kiyai pesantren Darussalam Parmeraan tentang metode sarajah al-mirast dalam memudahkan pembelajaran dan pengenalan hukum mawaris.

\section{METODE}

Kegiatan pengabdian yang dilaksanakan di Pesantren Darussalam parmeraan ini ditujukan kepada para guru/kiyai pesantren yang berjumlah 42 orang. Pengabdian ini dilakukan selama tiga hari, mulai tanggal 6 s.d 8 Februari 2021. Para guru diberikan pelatihan metode sajarah al-mirats dalam memahami hukum dan pembagian harta warisan. Melalui metode ini, diharapkan para guru mempunyai kemampuan tidak hanya dalam hal teori pembagian, tapi juga diisi dengan tatacara dan trik dalam penentuan warisan secara tepat, dalam hal ini mengacu kepada kasus-kasus yang sering muncul ditengah masyarakat.

pelatihan ini dirancang dalam berbagai kegaitan bertahap, yang terinci sebagai berikut:

1. Pemetaan permasalahan melalui komunikasi dengan pihak Yayasan Pesantren Darussalam, dalam hal ini untuk menemukan gambaran umum studi tentang pembelajaran dan tingkat pengetahuan para guru tentang konsep pembagian harta warisan.

2. Presentase materi: fase ini menjadi tahapan awal kegitan pengabdian, dimana para guru diberikan penjelasan secara utuh tentang konsep mawaris. 


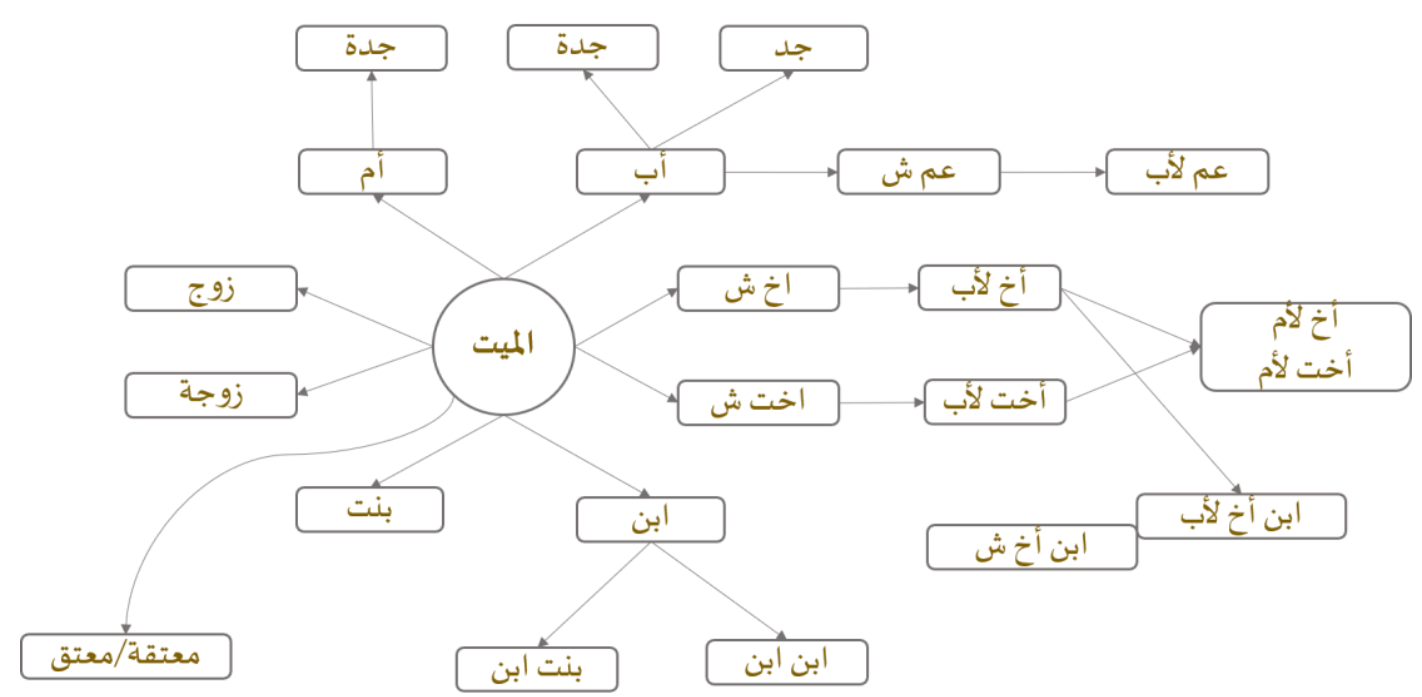

Gambar 1. .Bagan metode sajarah al-mirast

3. Tanya jawab: para guru selain mendengarkan pemaparan tentang konsep sajarah al-mirast juga diberikan kesempatan untuk berdiskusi tentang konsep-konsep tasawuf yang selama ini diketahui oleh guru

4. Kajian perbandingan metode; bersamaan dengan prosesi diskusi konsep sajarah al-mirast, para guru juga kemudian diberikan gambaran perbandigan metode pembelajaran yang efektif untuk kemudian diterapkan pada pembelajaran santri.

5. Pelatihan: setelah para guru/kiyai diberikan penjelasan tentang konsep sajarah al-mirats, maka tahap selanjutnya ialah mengadakan pelatihan penentuan ahli waris dan penghitungan. Para guru diberikan soal kasus (teori) untuk diselesaikan dengan cepat.

6. Penyelesaikan kasus: pada tahapan akhir, para guru dan tim pengabdi berdiskusi tentang kasus harta warisan yang sering muncul di masyarakat.

7. Evaluasi: tapahan evaluasi dilakukan untuk melihat peningkatan pemahaman para guru untuk menerapkan metode sajarah al-mirats.

Seluruh rangkain kegiatan pelatihan sajarah al-mirast dilaksanakan dengan sistem participation opproach, dimana semua para guru terlibat aktif dalam setiap Langkah kegiatan yang telah ditentukan.

\section{HASIL DAN PEMBAHASAN}

Kegiatan awal pengabdian dilakukan dalam bentuk koordinasi dengan pihak Pesantren Darassalam Parmeraan Padang
Lawas Utara, pada ini tim pengabdi STAIN Mandailing Natal mengidentifikasi permasalah pembelajaran dan pemahaman para guru terkait materi mawaris. Umumnya pembelajaran mawâris dipelajari secara berjenjang melalui kitab turast yang telah ditetapkan secara reguler oleh pihak pesantren. Pada gilirannya efek yang ditimbulkan ada dua, pertama, tidak semua para guru Pesantren Dasussalam menguasai meteri tentang mawâris, Kedua, pembelajaran mawaris yang diterapkan kepada santri bersifat konvensional yang menyebabkan tidak utuhnya pemahaman siswa pada konsep mawaris.

Dalam konteks mawaris, para guru Pesantren Darusssalam terbagi kepada tiga kategori, pertama, guru yang mengajar bidang studi farâid (mawaris) sebanyak 2 orang; kedua, guru yang berlatarbelakang pendidikan agama tetapi tidak mempunyai kajian spesifik di bidang mawaris; ketiga, guru yang berlatarbelakang pendidikan umum dan tidak pernah tersentuh kurikulum mawaris.

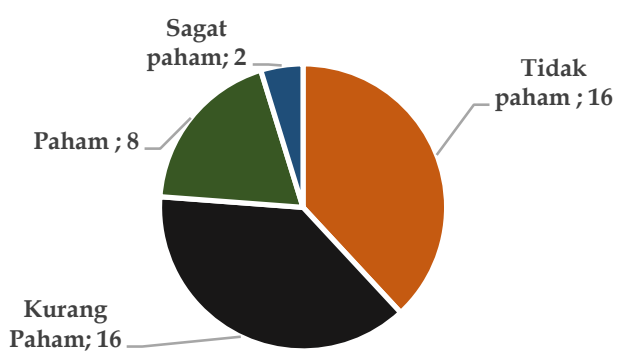

Gambar 2. Persentase awal tingkat pemahaman guru terhadap hukum mawaris 
Berdasarkan kategori yang disebutkan di atas, Tim Pengabdi kemudian mengidentifikasi pemahaman para guru tentang konsep mawaris. Dari hasil penelusuran ditemukan bahwa hanya 2 orang $(4,76 \%)$ guru yang mempunyai pengetahuan utuh tentang mawaris, hal ini dikarenakan mereka membidang mata pelajaran tersebut untuk diajarkan sehari-hari. Sementara itu terdapat 8 guru $(19,04 \%)$ yang menyatakan 'paham' dalam konsep mawaris, pada ini umumnya yang menjawab adalah yang berlatar belakang pesantren dan mempunyai kemampuan dalam mengakses kitab-kitab mawaris. Sementara para guru yang menjawab kurang paham dan tidak paham sebanyak 32 orang $(76 \%)$. Dominansi jawaban para guru ini disebabkan 2 hal, pertama, karena latar belakang pendidikan yang tidak tersentuh materi mawaris, mereka umumnya yang

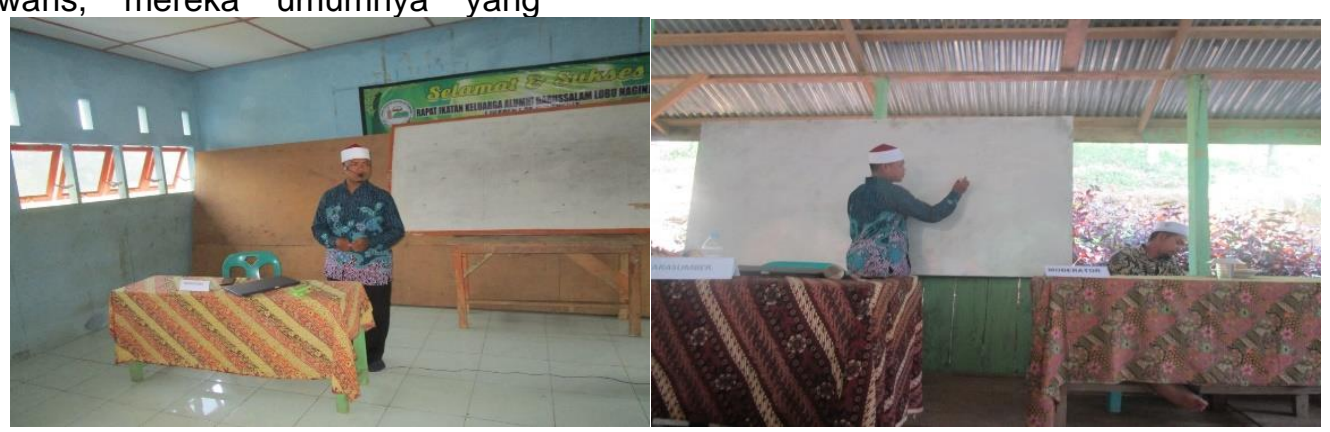

Gambar 3. Presentasi konsep metode sajarah al-mîrâst

Tahapan selanjutnya ialah melakukan diskusi konsep sajarah al-mirast. Proses ini para guru diberikan kesempatan kepada para guru untuk melakukan diskusi konsep, perbandingan materi, perbandingan penentuan kasus, dan penyelesaian masalah. Sejatinya proses ini bersamaan dengan kegaitan pemaparan konsep awal yang disebutkan di atas. Materi disampaikan dengan metode perbandingan, dimana para guru bisa membandinkan materi dalam kitab-kitab yang dipelajari di Pesantren dengan pendekatan metode sajarah al-mirast. Permasalahan utama pada ini ialah bagaimana jika pada gilirannya metode ini diterapkan dalam pola 3 kali pertemuan dalam pembelajaran yang akibatnya akan berpengaruh pada kurikulum pesantren yang memuat jenjang untuk mempelajari materi mawarist.

Setelah melewati proses presentase dan diskusi tentang sajarah al-mirast, para guru kemudian diberikan pelatihan untuk menyelesaikan beberapa kasus yang dipersiapkan. Bentuk ini sebagai bentuk evaluasi terhadap kegiatan yang dilakukan untuk melihat seberapa paham para guru mengenai konsep mawaris setelah mempelajari berlatarbelakang pendidikan umum dan mengampu mata pelajaran umum mengajar di Pesantren, dan, kedua, mempunyai pengetahuan tentang mawaris namun tidak mempunyai pemahaman yang baik.

Setelah melakukan dientifikasi permasalahan, maka kegaitan utama yang menjadi titik fokus pada pengabdian ini ialah memberikan pelatihan kepada para guru untuk mempermudah memahami mawaris, yaitu dengan mengenalkan metode sajarah almirast. Bagian ini melalui 3 (tiga) tahapan, pertama, memberikan penjelasan bagaimana cara mengenalkan ahli waris dengan konsep sajarah al-mirast; kedua, menjelaskan pembangian warisan berdasarkan peta konsep sajarah al-mirast; ketiga, menjelaskan penerapan pembagian warisan terhadap ahli waris.

metode sajarah al-mirast. Pelatihan diberikan dalam dua bentuk, secara pribadi dan secara kelompok. Ujian personal guru diberikan 4 permasalahan waris kemudian dijawab sendiri oleh para guru. Ujian kelompok diberikan kasus khusus untuk diselesaikan secara bersama yang terbahagi pada 8 kelompok.

Setiap test yang diberikan mempunyai skor maksimal 4 yang berbanding lurus dengan jumlah item pada setiap soal. Para guru harus tepat menentukan bagian dan perhitungan pada setiap bagian pada tiap soal, sehingga skor maksimal dalam penyelesaian soal adalah 16. Artinya, dalam setiap soal kesalahan dalam penentuan bagian dihitung satu kesalahan demikian juga sebaliknya. 


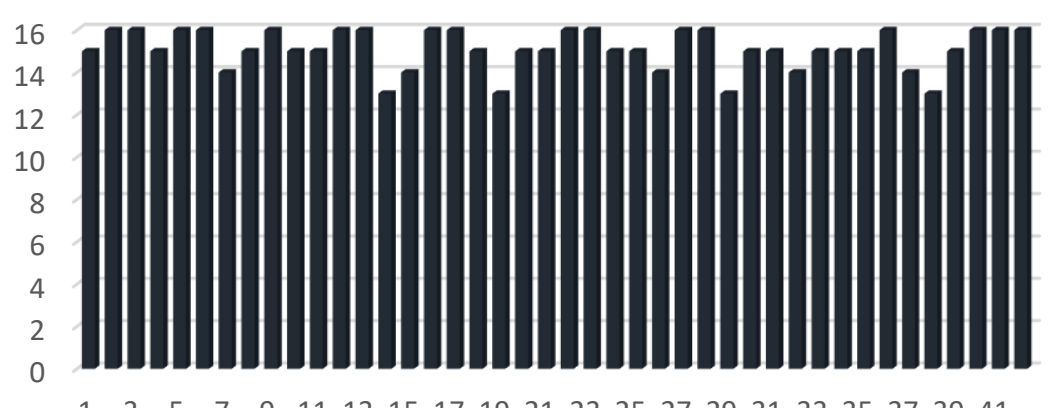

Gambar 4. Hasil Tes Personal Guru

Dari hasil tes yang diberikan, para guru umumnya telah mempunyai kemampuan dalam menentukan ahli warist dan mampu dalam menentukan bagian. Terdapat 18 guru $(42,85 \%)$ yang sudah matang dalam menyelesaikan soal test waris yang diberikan, 16 guru $(38,09 \%)$ mempunyai masalah dalam menentukan kasus mawaris ashobah. Sementara 8 orang guru (19\%) belum mampu

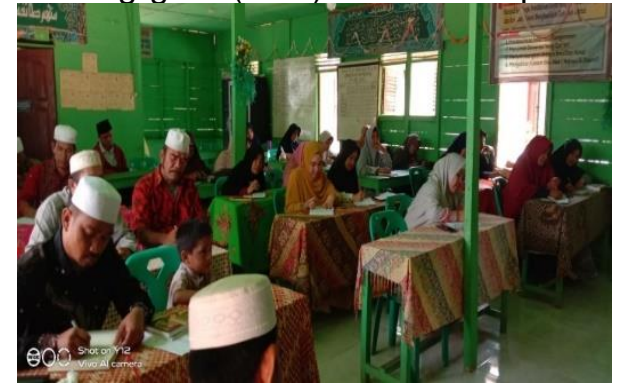

Gambar 5. Pelatihan penerapan sajarah mirast para guru.

Rangkaian kegiatan yang dilakukan di Pondok Pesantren Darussalam Parmeraan ialah untuk memberikan pandangan baru dalam hal inovasi pembelajarn. Karena dalam berbagai bentuk, pembelajaran bukanlah kegiatan stagnan, tetapi mesti mengacu kepada kebutuhan siswa. Melalu metode baru ini, diharapkan para guru Pesantren, mulai dari guru yang membidangi keagamaan maupun yang berkonsentrasi dalam ilmu-ilmu umum mengaplikasikan perhitungan kumulatif dalam pembagian warisan. Berlanjut dari evaluasi personal, test selanjutnya diberikan pada guru melalui kerja kelompok. Pada tahapan evaluasi kelompok, terlihat semua guru antusias dalam memberikan sumbangan hasil pemahaman. Pada ini, terliat tidak satu kelompok pun yang salah dalam menentukan bagian dan penghitungan.

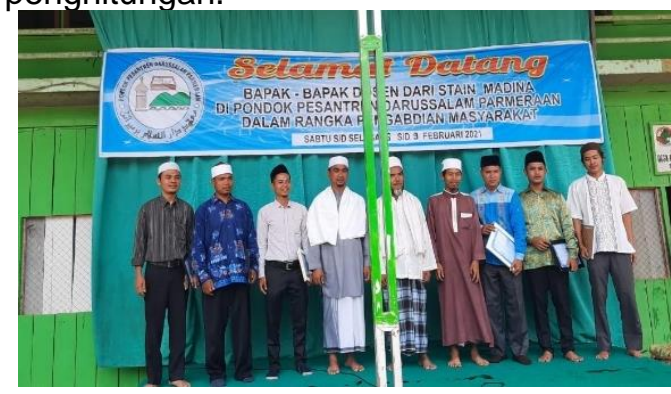

Gambar 6. Dokumentasi bersama

Pimpinan Ponpes Darussalam Parmeraan

mampu untuk memahami konsep mawarist yang menjadi salah satu ajaran Islam yang cukup urgen dipelajari karena menyangkut setiap individu.

Sebagai Langkah evaluasi bagi Tim pengabdi, survei kepuasan dilakukan untuk mengukur keefektifan penerapan metode sajarah al-mirast untuk meningkatkan pemahaman guru tentang konsep mawarist dan untuk membangun inovasi baru dalam pembelajaran mawaris kepada santri.

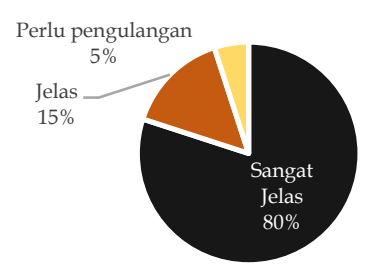

Gambar 6. Presentase kejelasan penyampaian konsep metode sajarah al-mirast

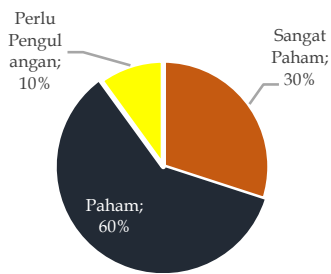

Gambar 7. Presentase tingkat pemahaman guru terhadap konsep metode sajarah al-mirast

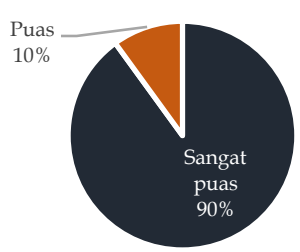

Gambar 8. Presentase tingkat kepuasan guru terhadap penjelasan konsep metode sajarah al-mirast 
Hasil survei yang dilakukan kepada guru Ponpes Darussalam Parmeraan setelah mengikuti pelatihan metode sajarah al-mirast menunjukkan presentase yang sangat efektif. $90 \%$ guru menyatakan sangat puas dengan pelatihan yang dilakukan, dan 10 menyataka Puas dengan catatan perlu pengulangan kembali. Demikia juga halnya dengan tangkat pemahaman para guru, mayoritas para guru menyatakan paham dengan kosep yang ditawarkan dengan presentase $30 \%$ sangat paha, $60 \%$ paham, dan terhadap 10\% guru menyatakan perlu pengulangan. Tidak jauh berbeda dengan kejelasan materi, $80 \%$ guru menyatakan sangat jelas karena disertakan dengan contoh-contoh konkret dan pelatihan, dan terdapat $5 \%$ guru menyarankan perlu adanya pengulangan kembali kegiatan pelatihan sajarah al-mirast.

\section{SIMPULAN}

Kegiatan pelatihan metode sajarah almirast yang dilakukan di Pesantren Darussalam Parmeraan Padang Lawas Utara berlangsung sebagaimana direncanakan. Para guru dari berbagai latarbelakang Pendidikan yang mengikuti kegiatan pelatihan juga mempunyai peluang yang sama untuk menepis misteri sulitnya mempelajarai materi mawaris. Tingkat kepuasan para guru pada gilirannya direkomendasikan untuk melakuan pengabdian yang sama kepada pesantren-pesantren serupa untuk mampu menampilkan inovasi bari dalam pembelajaran agama, khususnya materi mawaris.

\section{DAFTAR RUJUKAN}

Fahmi, Ahmad Nur. (2017) Peningkatan Hasil Belajar Siswa Materi Mawaris Menggunakan Sparkol Videoscibe, Pedagogia, Jurnal IImu Pendidikan, Vol. 17/(3), 229-238. https://doi.org/10.17509/pdgia.v17i3. 20788

Hasanuddin. (2020). Fiqh Mawaris: Problematika dan Solusi, Jakarta: Kencana

Kurnia, Alaika M. Bagus \& Khairul Muaddib. (2020). Fikih Mawaris, Sukabumi: Haura Utama

Muammar Ghaddafi hanafiah (2019), Isu Membid'ahkan Amalan Masyarakat Melayu: Analisis Wacana Media Massa, Jurnal Komunikasi: Malaysian Journal Of Communication, 35/2, 6886. https://doi.org/10.17576/JKMJC2019-3502-05

Nurdin, Penarapan Aplikasi At-Tashil Pada Materi Mawaris Pada Balai Diklat Kecamatan Aceh Tahun 2020, Jurnal

Mudarrisuna, Vol. 10/(3), 402427.http://dx.doi.org/10.22373/jm.v10 i3.7693

Sujud, Amru, Djuanda BJ, sandy vriada. (2017). Rancangan Program Aplikasi AlFaraidh Sebagai Media Pembelajaran Mawaris di MAN Model Banda Aceh. Jurnal JTIK: Jurnal Teknologi Informasi Dan Komunikasi, Vol. 1/(1), 15-23.

https://doi.org/10.35870/itik.v1i1.29

Suryati (2017). Hukum Mawaris Islam, Yogyakarta: ANDI 